\title{
Onshore-offshore variations in copepod community structure off the Oregon coast during the summer upwelling season
}

\author{
Cheryl A. Morgan ${ }^{1, *}$, William T. Peterson ${ }^{2}$, Robert L. Emmett ${ }^{2}$ \\ ${ }^{1}$ Cooperative Institute for Marine Resources Studies, Oregon State University, Hatfield Marine Science Center, \\ 2030 S. Marine Science Dr., Newport, Oregon 97365, USA \\ ${ }^{2}$ National Marine Fisheries Service, Northwest Fisheries Science Center, Hatfield Marine Science Center, \\ 2030 S. Marine Science Dr., Newport, Oregon 97365, USA
}

\begin{abstract}
During the summer of 1994, 1996, and 1997, we conducted hydrographic and plankton surveys of the upper $70 \mathrm{~m}$ in the nearshore, the continental shelf, and off-shelf oceanic waters off Oregon, USA. Copepod densities and biomass were estimated along 4 transects from each cruise. The on-shelf copepod biomass was 2.8 times greater than off-shelf biomass. Nonmetric multidimensional scaling identified an on-shelf and an off-shelf copepod community. The change in community composition usually occurred at or slightly offshore of the continental shelf break, defined here as $180 \mathrm{~m}$ water depth. Indicator-species analysis identified the subarctic neritic species, Calanus marshallae, Pseudocalanus mimus, and Acartia longiremis, as good indicators of continental shelf waters. 'Warm water' species Mesocalanus tenuicornis, Calocalanus styliremis, Clausocalanus spp., and Ctenocalanus vanus were indicators of off-shelf waters. The copepod communities off the coast of Oregon during the summer upwelling season reflect the origins of the dominating currents within each habitat. The coastal copepod community is subarctic neritic in origin, consistent with southward coastal flows. The offshore copepod community is a mixture of species with origins in the Transition Zone as well as species that are typical of the coastal region of the California Current off central and southern California. We speculate that the central and southern California Current species are present in offshore waters of Oregon in summer because they are transported north with the Davidson Current in winter but, with the initiation of the upwelling season in spring, they are transported into offshore waters where they establish viable populations.
\end{abstract}

KEY WORDS: Community structure $\cdot$ Copepod distributions $\cdot$ Nonmetric multidimensional scaling · Oregon Resale or republication not permitted without written consent of the publisher

\section{INTRODUCTION}

Two different water types control the hydrography of the surface ocean off the Oregon coast during summer months. Continental shelf waters are dominated by subarctic coastal water transported south from southern British Columbia and the Gulf of Alaska. Oceanic waters offshore of the continental shelf represent an inshore arm of the California Current and originate to the west, as part of the West Wind Drift and the so-called Transition Zone (Hickey 1998). The summer hydrography of shelf and slope waters is also influenced by wind-driven coastal upwelling, whereby cold, salty, nutrient-rich, deep water is brought to the surface where it displaces coastal and offshore waters, creating strong temperature and salinity gradients in both continental shelf and slope waters (Hickey 1998). As the coastal waters move south along the Oregon and California coasts, they warm due to solar heating and salinity rises as greater volumes of upwelled water mix with Transition Zone water (Hickey 1998).

Given the different origins of waters found off the coastal northeast Pacific, we expected that each water type would carry a different or unique zooplankton assemblage into the region (Johnson \& Brinton 1963). Moreover, given the onshore-offshore gradients in 
hydrographic conditions, we also expected strong cross-shelf zonation in zooplankton community structure. Subarctic neritic species should dominate onshelf waters, while oceanic, Transition Zone species should dominate off-shelf waters.

Cross (1964) and Cross \& Small (1967) were the first to describe zonation patterns for zooplankton off Oregon. Cross (1964) sampled from 5 to 105 nautical miles from shore along 4 transect lines off the Columbia River, Newport, Coos Bay and the Oregon-California border. They reported distributions for only a few of the most common coastal species and strong zonal gradients in abundances were noted for Pseudocalanus minutus (=mimus), Acartia longiremis and Centropages mcmurrichi (=abdominalis). For offshore species in their samples, they reported only on A. danae and showed that during summer this species was found solely in offshore waters (Cross \& Small 1967).

Peterson (1972) conducted 7 cruises on the continental shelf and in oceanic waters off Washington and Oregon in summer 1961 and 1962, and was the first to report distribution patterns of all dominant coastal and oceanic copepod species. Of the common copepod species (i.e. species that occurred in $>15 \%$ of the samples), 2 were found chiefly in shelf waters (Acartia longiremis and Pseudocalanus minutus [=mimus]) and 5 were found chiefly in oceanic waters (Calanus [=Mesocalanus] tenuicornis, Calocalanus styliremis, Clausocalanus arcuicornis, C. pergens and Paracalanus spp).

Peterson \& Miller (1975) and Peterson et al. (1979) reported on seasonal variations in zonation patterns of copepods in continental shelf waters. They described a copepod community during summer which consisted of a nearshore group including Acartia hudsonica and Centropages abdominalis, which was most abundant within 5 to $10 \mathrm{~km}$ of the shore, and a midshelf group dominated by A. longiremis, Pseudocalanus spp. and Calanus marshallae, which was found chiefly in midshelf and outer shelf waters. Landry \& Lorenzen (1989) identified similar species groups for the shelf waters off Washington.

In June or July 1994 through 1998, the Estuarine and Ocean Ecology Division of the National Marine Fisheries Service conducted plankton and oceanographic surveys off the coasts of Oregon and Washington in order to describe onshore-offshore variations in the distribution and abundance of northern anchovy Engraulis mordax and Pacific sardine Sardinops sagax eggs and larvae, and zooplankton (Bentley et al. 1996). We analyzed a subset of these zooplankton samples collected in 1994, 1996, and 1997 to examine and describe the onshore-offshore patterns in copepod community structure off the coast of Oregon. The objectives of this paper include a description of copepod community structure (using ordination techniques), comparison of on-shelf versus off-shelf com- munities, and determination of the interannual variations in copepod species dominance using indicatorspecies analysis. Finally, we relate differences in copepod community structure to oceanographic gradients.

\section{MATERIALS AND METHODS}

Field methods. Surveys were conducted with the RV 'Sea Otter' during 6 to 26 July 1994 and 14 to 25 July 1997, and with the RV 'McArthur' during 9 to 21 June 1996 over a grid of up to 281 stations along up to 14 latitudinal transect lines off the coast of Oregon (Fig. 1). The transects extended from 1.9 to $185 \mathrm{~km}$ offshore and ranged from the Columbia River $\left(46.27^{\circ} \mathrm{N}\right)$ to just south of Cape Blanco $\left(42.62^{\circ} \mathrm{N}\right)$. Each transect consisted of 17 to 20 stations, which began at either 1.9 or $9.3 \mathrm{~km}$ from shore and were evenly spaced at $9.3 \mathrm{~km}$ thereafter.

Vertical net tows were conducted using the CALCOFI (California Cooperative Oceanic Fisheries Investigations) protocol (Smith et al. 1985) with the primary objective of collecting and quantifying the distribution and abundance of northern anchovy and Pacific sardine eggs and larvae. Tows were made at each station from $5 \mathrm{~m}$ off the bottom, or from a maximum of $70 \mathrm{~m}$, to the surface with a $0.25 \mathrm{~m}$ diameter CalVET net fitted with $150 \mu \mathrm{m}$ mesh: the filtration area ratio for this net was 9.3, and therefore clogging should not have been a problem (Smith et al. 1985). In addition, we did not see significant amounts of phytoplankton in any of the samples that were counted for zooplankton. Plankton samples were preserved in $5 \%$ buffered formalin. Conductivity and temperature profiles were recorded simultaneously with a Seabird SBE 19 CTD (conductivity, temperature, depth) meter, and salinity and density were later derived from these measurements. Water samples were taken from a depth of $3 \mathrm{~m}$ with a Niskin bottle, filtered at sea, and analyzed for chl $a$ in the laboratory using standard fluorometric techniques.

For this paper, a total of 186 zooplankton samples were analyzed from 4 transects in each year: Columbia River (CR) $\left(46.27^{\circ} \mathrm{N}\right)$, Cape Falcon $(\mathrm{CF})\left(45.76^{\circ} \mathrm{N}\right)$, Newport $(\mathrm{NH})\left(44.59^{\circ} \mathrm{N}\right)$, and Coquille River $(\mathrm{CQ})\left(43.13^{\circ} \mathrm{N}\right)$ in 1994 and 1996 or the Cape Blanco (CB) $\left(42.62^{\circ} \mathrm{N}\right)$ in 1997 (Fig. 1). In the laboratory, samples were rinsed in freshwater, poured into graduated cylinders and allowed to settle to determine settled volume. The sample was then diluted to 5-10 times the settled volume, suspended by mixing with a spatula, and aliquots were removed for counting with a $1.1 \mathrm{ml}$ Hensen-stempel pipette. Two aliquots were counted, unless more were needed to achieve a total of 300 to 500 animals. Copepods were identified to species when possible, or otherwise to genus. Copepods were grouped by copepodite, adult male or adult female, except for Calanus marshallae, $C$. 


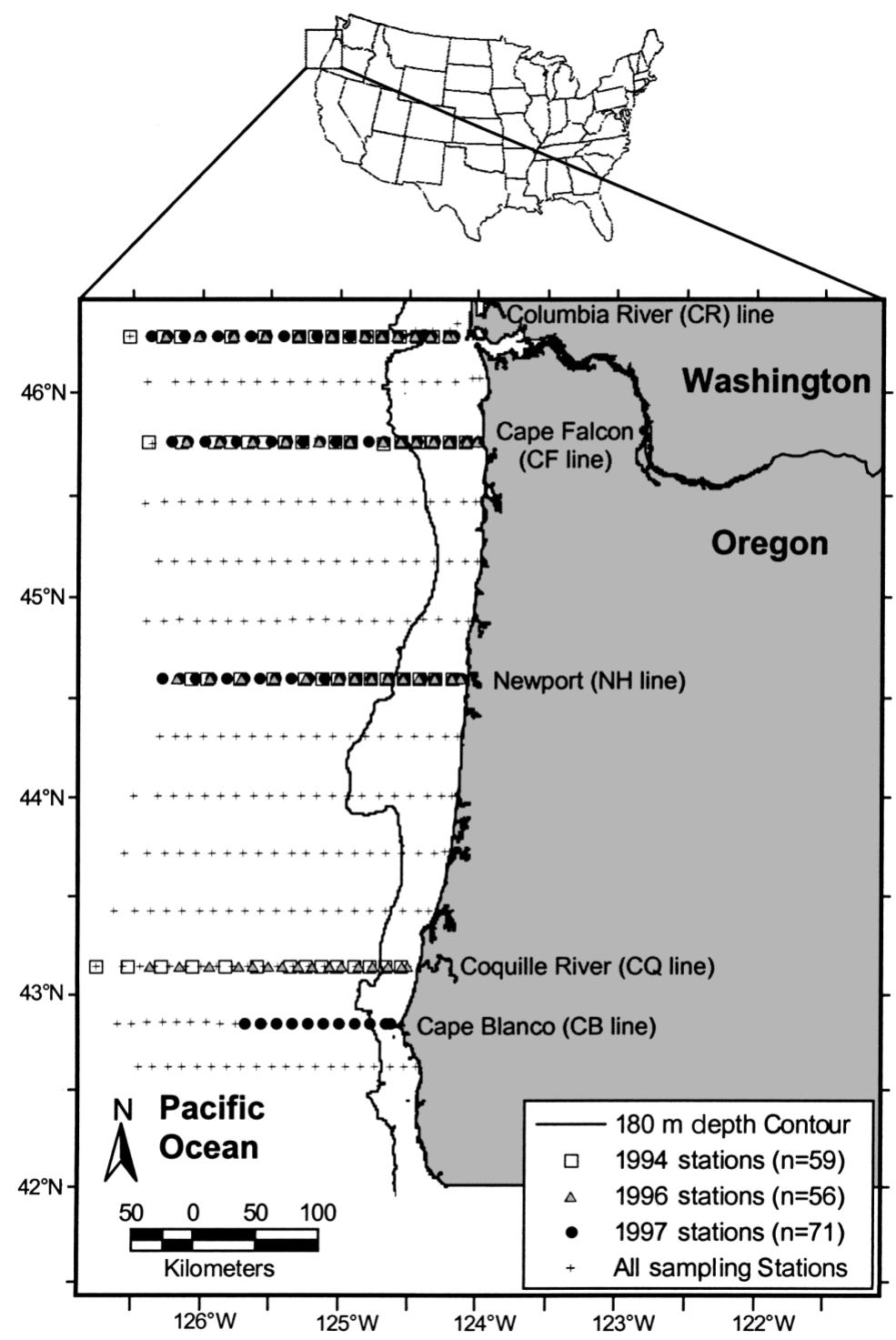

Fig. 1. Map of the study area showing location of stations sampled along the Oregon coast, USA during 6 to 26 July 1994 (口), 9 to 21 June 1996 $(\Delta)$, and 14 to 25 July $1997(\bullet)$. Temperature and salinity (1 m depth) were recorded at all the oceanographic stations (+). Copepod densities and biomass were estimated along 4 hydrographic transects; Columbia River (CR), Cape Falcon (CF), Newport (NH), and Coquille River (CQ) (1994 and 1996) or Cape Blanco (CB) (1997). The dashed line indicates the $180 \mathrm{~m}$ depth contour (shelf break)

pacificus, Mesocalanus tenuicornis, Euclanus californicus, and Neocalanus species, which were also identified to copepodite developmental stage. The counts were converted into densities (number $\mathrm{m}^{-3}$ ) using the mouth area of the net and the distance of the tow (m). Biomass of a given species was calculated by multiplying the number $\mathrm{m}^{-3}$ by the carbon weight of individuals of a given developmental stage. Values for carbon are derived from literature values or from our own estimates of weight (see Peterson et al. 2002, Table 2).
Sampling was conducted at stations without regard for time of day. Thus, because some copepods have been shown to exhibit vertical migration behavior, the possibility of a day and/or night bias exists. Therefore, we used the Mann-Whitney $U$-test to compare the median biomass for day versus night samples on and off of the shelf. Of the 6 comparisons ( $3 \mathrm{yr} \times$ on- or off-shelf), only 1 (1997 on-shelf) had a p-value $<0.05(\mathrm{p}=0.04)$. For half of the 6 comparisons, day biomass was higher than night, and for 3 comparisons night biomass was higher than day. Therefore, we felt it was reasonable to combine the day and night samples together for on- versus off-shelf comparisons. In addition, several published studies carried out in northern California Current waters have shown no statistically significant difference in density or biomass between day and night for the dominant copepod species which we discuss (Peterson 1972, Shaw \& Robinson 1998, Peterson \& Keister 2002).

Data reduction and statistical methods. Contour maps of $1 \mathrm{~m}$ temperature and salinity and of copepod density and biomass were generated using kriging as the gridding method in Surfer (Golden Software, V7.0). Distribution and abundance maps of the individual copepod species were created using a layer of shaded raster images of the grid created by kriging combined with a classed post map, which shows the true values at each of the individual sampling stations where samples were quantified. A linear kriging variogram with an anisotropy ratio of 1 (no anisotropy) and no search rules was used. All statistical analyses were conducted using the computer software PC-ORD V4.36 (McCune \& Mefford 1999). For all analyses, copepod densities were first summed for all lifehistory stages, excluding eggs and nauplii. All data were $\log (x+1)$ transformed before statistical analysis. The data were then arranged into 4 species and 4 environmental matrices (one for each year and one with all years combined). The species or environmental variables formed the columns and stations formed the rows. The size of the species matrix was reduced by eliminating 'rare' taxa (operationally defined as those species occurring at $<5 \%$ of the stations for the individual years and $<2 \%$ of the stations for all years combined, and which comprised $<1.5 \%$ of the total population at the sites where they were present). After transformation, the data were analyzed for outliers. There were no species in any year with an average distance from the mean of more than 2 standard deviations from the mean of distances between species.

Nonmetric Multidimensional Scaling (NMDS) (Kruskal 1964, Mather 1976) was used to ordinate 
sample units in species space, to identify station clusters with similiar copepod communities, and to relate them to environmental variables. NMDS has proven useful in analyzing marine community data (Field et al. 1982, Hosie \& Cochran 1994, Chiba et al. 2001). NMDS is an iterative search for a ranking and placement of $n$ entities on $k$ dimensions (axes) that minimizes the stress of the $k$-dimensional configuration. The calculations are based on an $n \times n$ distance matrix calculated from the $n \times p$-dimensional main matrix, where $n$ is the number of rows and $p$ is the number of columns in the main matrix. 'Stress' is a measure of departure from monotonicity in the relationship between the dissimilarity (distance) in the original $p$-dimensional space and distance in the reduced $k$-dimensional ordination space. It quantifies between-site dissimilarity and arranges all sites in $k$-dimensional space, such that the rank order of the between-site dissimilarities corresponds as closely as possible to the rank order of between-site distances (McCune \& Mefford 1999). Thus, the closer that 2 stations are in species space, the closer the species composition of the stations will be. Runs were made using the Sørensen distance measure (also known as the Bray-Curtis coefficient, Bray \& Curtis 1957), 4 axes, 150 iterations, 10 runs of real data and 30 randomized runs. Plots and output of instability and stress were examined to find the number of axes at which the reduction in stress gained by adding another axis was acceptably small (see Mather 1976). In this dataset, all ordinations were best described by 2 axes (instability < 0.005). The orientation of axes derived from NMDS is arbitrary, and therefore we rotated the plots such that the first axis corresponds to the axis of maximum environmental variability.

The environmental data matrices contained values of temperature $\left({ }^{\circ} \mathrm{C}\right)$, salinity, and density (sigma- $t$ ) at depths of 1 and $30 \mathrm{~m}$, chl a concentration at $3 \mathrm{~m}$ depth, longitude and latitude. They also contained grouping variables for stations located on versus off the continental shelf. The continental shelf group, delineated by the $180 \mathrm{~m}$ isobath, consisted of all stations inshore of 25 miles on the CR transect, inshore of 20 miles on the $\mathrm{CF}$ and $\mathrm{NH}$ transects, and inshore of 10 miles on the $\mathrm{CQ}$ and $\mathrm{CB}$ transects (Fig. 1).

The nonparametric Multi-Response Permutation Procedure (MRPP) (Mielke 1984, Zimmerman 1985, McCune \& Mefford 1999) was used to test the hypothesis of no difference in the copepod community composition between samples taken from the on- and off-shelf stations. MRPP is similar to the $t$-test and the 1-way ANOVA $F$-test, without requiring the assumptions of normality and homogeneity of variances. To test for differences between years, MRPP was run separately for on- and off-shelf stations using year as a grouping variable. The Sørensen distance measure was used in all cases.
Indicator species analysis (ISA) (Dufrene \& Legendre 1997) was used to define and describe which species were typical of on- and off-shelf station groups among the 3 yr. The indicator value for a species in a group is calculated as the product of the relative abundance of the species in the group (the mean abundance in the group/the sum of the mean abundances in all groups) and the frequency of occurrence of the species in the group samples. Indicator values can range from 0 (no indication) to 100 (perfect indication). A score of 100 means that the species was present in all samples in the group and was absent from all samples in other groups. The highest indicator value for each species is tested for statistical significance using a Monte Carlo randomization technique.

\section{RESULTS}

\section{Temperature and salinity}

During the July 1994 survey, sea surface temperatures (SST) in the sampling area ranged from 8.6 to $16.7^{\circ} \mathrm{C}$ (Fig. 2). Coastal upwelling was occurring off central and southern Oregon as indicated by the presence of water $<9^{\circ} \mathrm{C}$ and salinity greater than 33. During the June 1996 survey, SST ranged from 7.2 to $15.4^{\circ} \mathrm{C}$. Coastal upwelling was most pronounced off central Oregon, with cold high-salinity water just south of Newport. In the July 1997 survey, SST ranged from 9.1 to $18.8^{\circ} \mathrm{C}_{i}$ the higher SSTs offshore were the result of a strong downwelling event (Strub \& James 2002) likely associated with the 1997-1998 El Niño. Coastal upwelling during this cruise was weak compared to the other cruises, and again was most pronounced just south of Newport.

\section{Copepod density and biomass}

Table 1 lists the average densities for the dominant species in each of the $3 \mathrm{yr}$. From this table, it is clear that the dominant species in on-shelf waters included Calanus marshallae, Pseudocalanus mimus, Centropages abdominalis, and Acartia longiremis. In offshore waters, the dominant taxa in each of the $3 \mathrm{yr}$ were Mesocalanus tenuicornis, Paracalanus parvus, Clausocalanus spp., Ctenocalanus vanus, and P. mimus. Two other species, Calanus pacificus and Oithona similis, were abundant in our samples, but were equally abundant on and off the shelf. During 1997, an El Niño year, P. parvus was the most abundant species in on-shelf waters.

Average copepod biomass during each survey was similar among years. For the on-shelf stations, biomass (SE) was $15.9(2.4), 14.0$ (1.4) and 19.6 (2.5) $\mathrm{mg} \mathrm{C} \mathrm{m}^{-3}$ for 1994, 1996 and 1997 respectively. For the off-shelf 

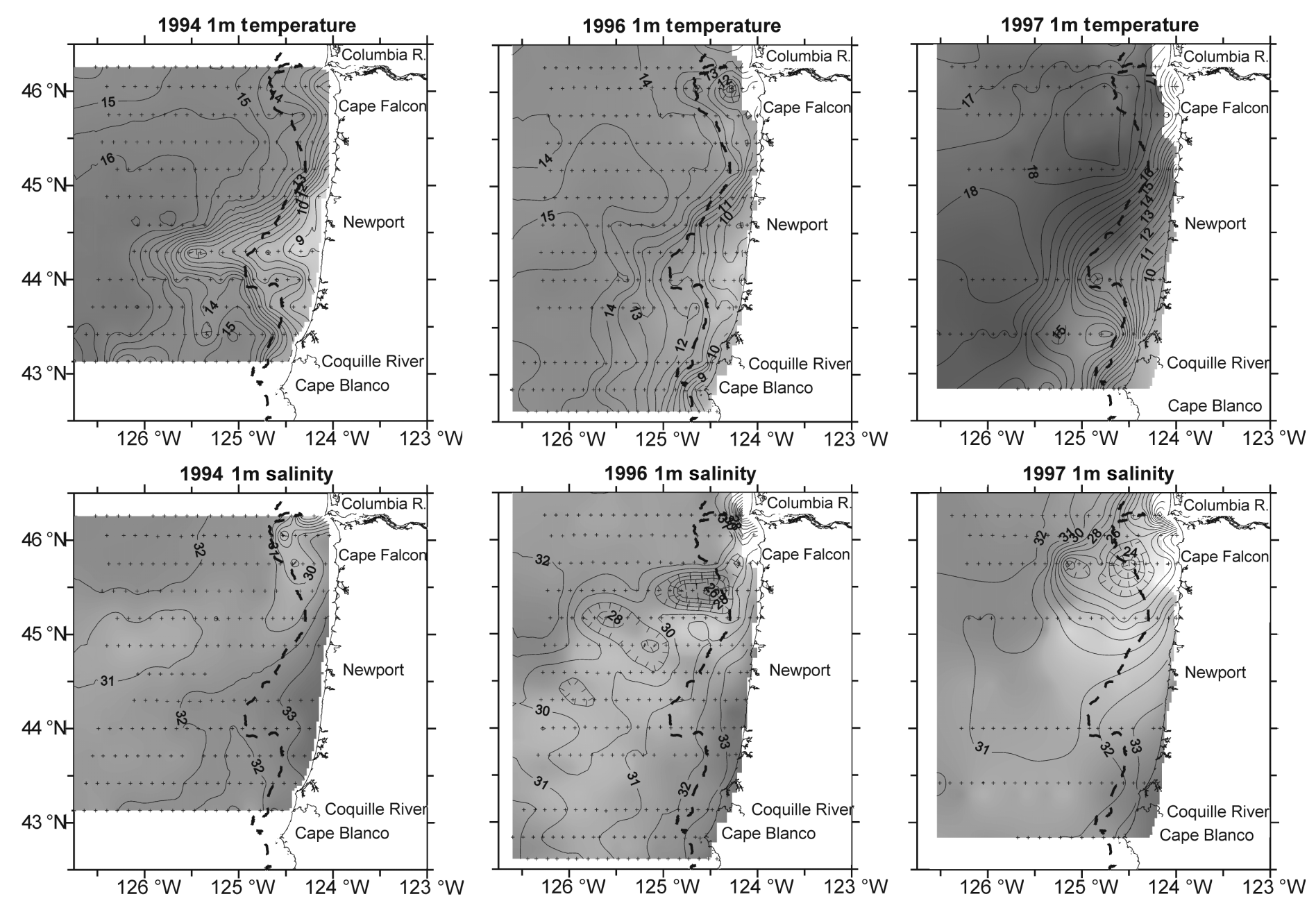

Fig. 2. Sea surface $\left(1 \mathrm{~m}\right.$ depth) temperatures $\left({ }^{\circ} \mathrm{C}\right)$ and salinities along the Oregon coast, USA during 6 to 26 July 1994,9 to 21 June 1996 and 14 to 25 July 1997 . The dashed line indicates the $180 \mathrm{~m}$ depth contour

stations, the corresponding biomass values were 5.7 $(0.6), 7.7(0.9)$ and $4.2(0.4) \mathrm{mg} \mathrm{C} \mathrm{m}^{-3}$. The on-shelf and off-shelf copepod biomasses were significantly different in all years (Mann-Whitney $U$-test, $\mathrm{p}<0.0001$ ). Biomass and density were generally highest in the north and showed strong onshore-offshore gradients (Fig. 3).

\section{Community structure}

Using our matrix of species abundance at on- and off-shelf stations, we tested for differences in community structure using MRPP. For this analysis we differentiated stations by water depth. Stations $<180 \mathrm{~m}$ deep were defined as on-shelf, while stations $>180 \mathrm{~m}$ deep as off-shelf. We also tested for differences among years. MRPP revealed that copepod community structure of on- and off-shelf stations were significantly different $(p<0.0001)$ in all years. Copepod community structure was also different among years $(\mathrm{p}<0.0001)$ both on and off the shelf.

\section{Ordination of stations in species space}

NMDS showed that the stations on and off the continental shelf occupied distinct places in species space, demonstrating (as with MRPP analysis) that there were distinct differences in copepod community structure (Fig. 4). Monte Carlo analysis gave a probability of only 0.03 that these patterns could have been obtained by chance. The relationship between the distance in the ordination space and the distance in physical space was highly significant $(p<0.0001)$ (Table 2$)$.

Significant relationships between the ordination axis and environmental variables were found. Axis 1 was strongly correlated with $30 \mathrm{~m}$ temperature and density, longitude, and $1 \mathrm{~m}$ temperature (Table 2). Higher temperatures were associated with off-shelf samples, while denser waters were associated with the on-shelf samples (Fig. 4). Chlorophyll a was also highly correlated with Axis 1 in 1994 and 1997 but not in 1996. 
Table 1. Average densities (no. $\mathrm{m}^{-3}$ ) and SE (in parentheses) of copepod species in waters on and off the continental shelf off Oregon in summer 1994, 1996, and 1997. The number of samples in each category is in parentheses beneath the respective heading.

The 4 species in bold are the dominant on-shelf species

\begin{tabular}{|c|c|c|c|c|c|c|}
\hline \multirow[t]{2}{*}{ Species } & \multicolumn{2}{|c|}{1994} & \multicolumn{2}{|c|}{1996} & \multicolumn{2}{|c|}{1997} \\
\hline & $\begin{array}{c}\text { On-shelf } \\
(14)\end{array}$ & $\begin{array}{l}\text { Off-shelf } \\
\text { (45) }\end{array}$ & $\begin{array}{c}\text { On-shelf } \\
(18)\end{array}$ & $\begin{array}{l}\text { Off-shelf } \\
(38)\end{array}$ & $\begin{array}{c}\text { On-shelf } \\
(17)\end{array}$ & $\begin{array}{c}\text { Off-shelf } \\
\text { (54) }\end{array}$ \\
\hline Calanus marshallae Frost & $267(108)$ & $38(15)$ & 169 (28) & $21(12)$ & $110(21)$ & $1(4)$ \\
\hline Calanus pacificus Brodsky & $19(11)$ & $42(11)$ & $14(6)$ & $17(4)$ & $26(10)$ & $17(22)$ \\
\hline Mesocalanus tenuicornis (Dana) & & $46(12)$ & & $10(3)$ & $3(2)$ & $15(20)$ \\
\hline Eucalanus californicus Johnson & $1(1)$ & $1(1)$ & $2(1)$ & $14(4)$ & & 9 (13) \\
\hline Paracalanus parvus (Claus) & $126(33)$ & 467 (69) & $73(20)$ & $501(91)$ & $3315(874)$ & $863(872)$ \\
\hline Calocalanus styliremis Giesbrecht & & $12(3)$ & $2(1)$ & $30(6)$ & $0.3(0.3)$ & $49(52)$ \\
\hline Clausocalanus spp. & $7(5)$ & 97 (19) & $11(5)$ & 207 (56) & 39 (19) & $87(92)$ \\
\hline Ctenocalanus vanus Giesbrecht & & $63(13)$ & $3(2)$ & $131(25)$ & $11(8)$ & 133 (109) \\
\hline Pseudocalanus mimus (Frost) & $1457(240)$ & $435(80)$ & 1295 (125) & 707 (201) & $1346(196)$ & $161(269)$ \\
\hline Metridia pacifica Brodsky & $9(5)$ & $22(5)$ & $72(35)$ & $51(10)$ & $22(8)$ & $14(28)$ \\
\hline Centropages abdominalis Sato & $61(22)$ & $7(2)$ & $15(7)$ & $12(9)$ & $540(218)$ & $13(36)$ \\
\hline Candacia bipinnata (Giesbrecht) & & $1(1)$ & & $2(1)$ & & $6(9)$ \\
\hline Acartia spp. unidentified. copepodites & $473(113)$ & $132^{*}(36)$ & $67(23)$ & $22(16)$ & $147(42)$ & $18(34)$ \\
\hline Acartia danae Giesbrecht & & $4(1)$ & & $0.2(0.2)$ & & $8(13)$ \\
\hline Acartia longiremis (Lilljeborg) & $974(214)$ & $112(54)$ & $80(24)$ & $17(10)$ & 199 (48) & $5(14)$ \\
\hline Acartia tonsa Dana & $5(2)$ & $3(1)$ & $1(1)$ & $0.3(0.4)$ & $4(3)$ & $1(2)$ \\
\hline Acartia hudsonica Pinhey & $9(5)$ & $1(1)$ & $7(5)$ & & $17(7)$ & \\
\hline Microsetella sp. & $2(1)$ & $2(1)$ & $1(1)$ & $21(4)$ & $1(1)$ & $13(12)$ \\
\hline Corycaeus anglicus Lubbock & $2(2)$ & $9(2)$ & $11(5)$ & $26(11)$ & $24(7)$ & $10(16)$ \\
\hline Oithona similis Claus & $1677(273)$ & 1865 (131) & $1305(180)$ & $1872(233)$ & $1730(191)$ & 1549 (824) \\
\hline All other copepod species & $2(2)$ & $12(2)$ & $6(2)$ & $18(2)$ & $15(3)$ & $9(1)$ \\
\hline Total copepods & $618(65)$ & 303 (25) & 364 (39) & 299 (23) & 721 (109) & $233(18)$ \\
\hline
\end{tabular}
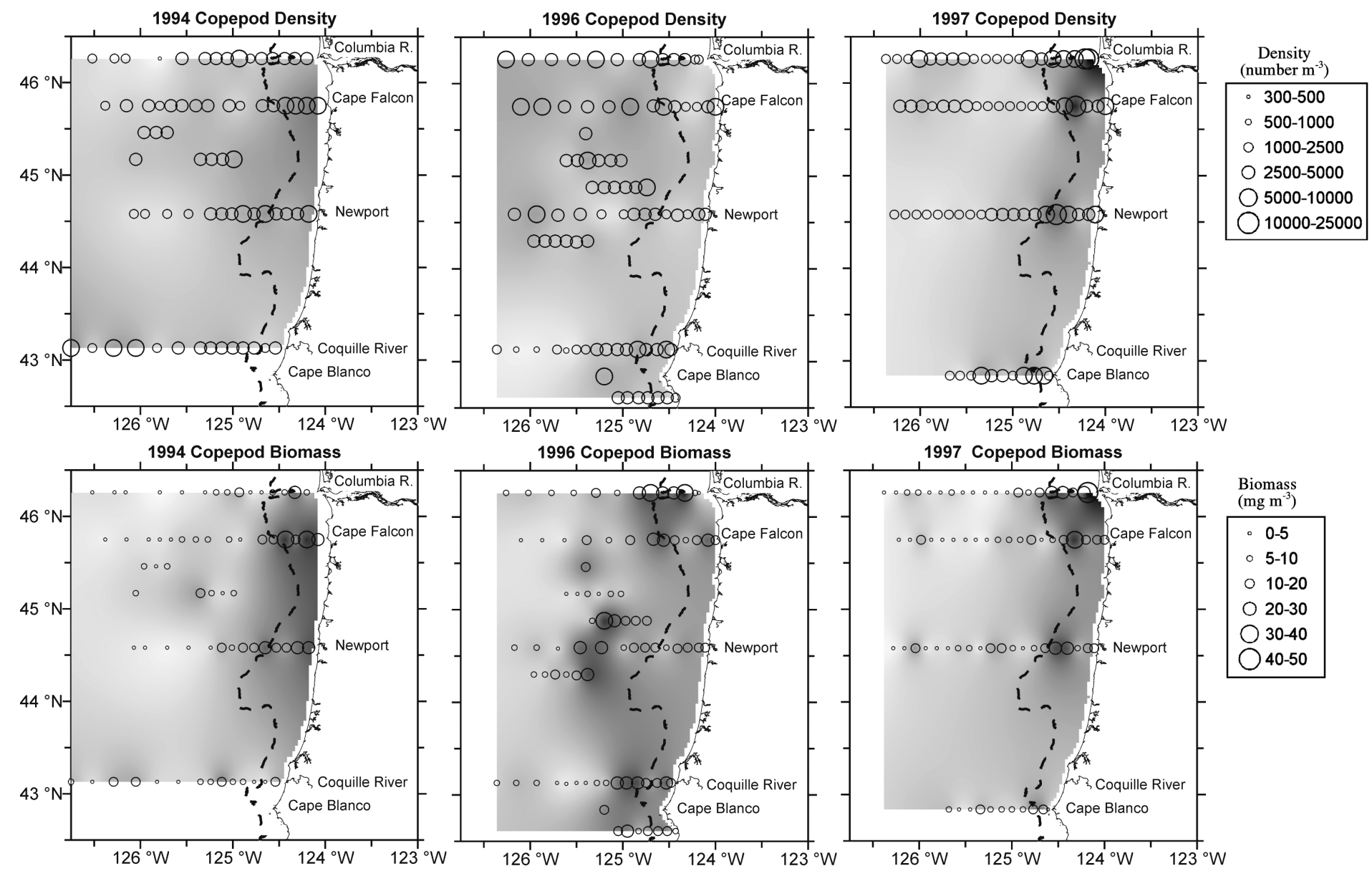

Fig. 3. Copepod density (no. $\left.\mathrm{m}^{-3}\right)$ and biomass $\left(\mathrm{mg} \mathrm{m}^{-3}\right)$ estimates off the Oregon coast, USA from stations sampled (+) along 4 hydrographic transects: Columbia River (CR), Cape Falcon (CF), Newport (NH), and Coquille River (CQ) during 6 to 26 July 1994 and 9 to 21 June 1996; CR, CF, NH, and Cape Blanco (CB) during 14 to 25 July 1997. The dashed line indicates the $180 \mathrm{~m}$ depth contour 


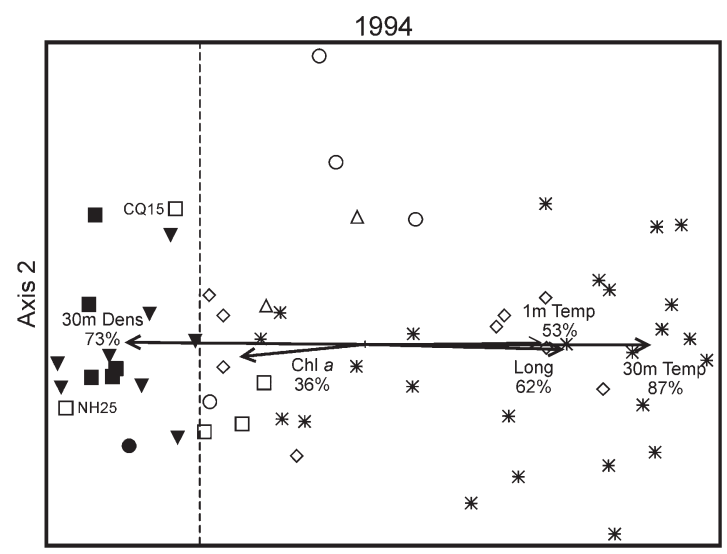

Axis 1

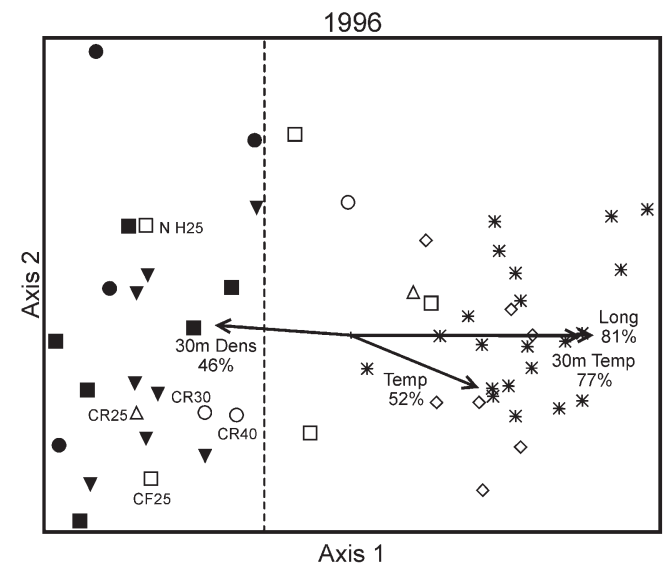

Axis 1

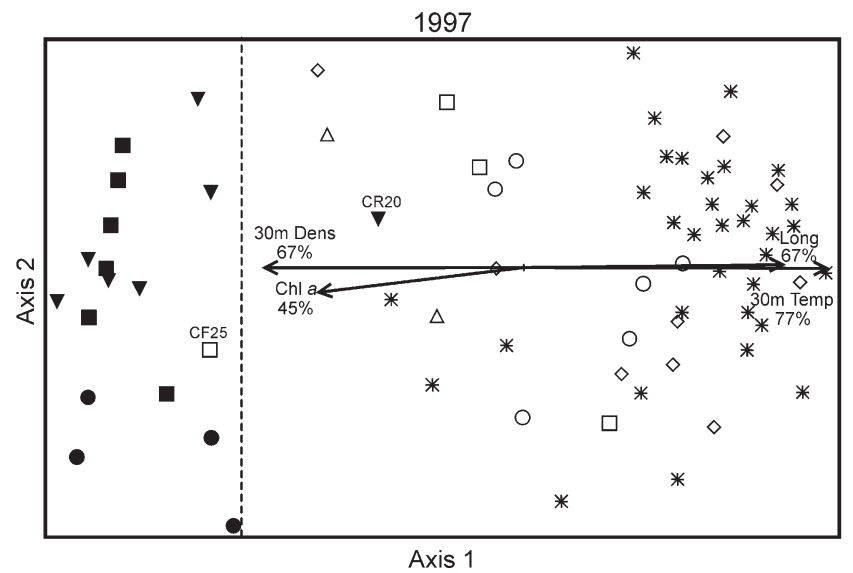

The NMDS ordination of stations classified by water depth revealed good separation between on-shelf stations (solid symbols; clustered on the left of Fig. 4) and off-shelf stations (open symbols; clustered on the right side of Fig. 4). There was, however, some overlap for stations in all of the depth bins. Though $180 \mathrm{~m}$ water depth did not always define the break point in community composition, data from stations less than $300 \mathrm{~m}$ deep did divide the 2 communities in almost every case. This suggests that the true break in the copepod community composition is closely associated with the location of the continental shelf break, but is not a step-like change.

\section{Indicator species analysis}

ISA revealed similarities among years for which copepod species were indicators of shelf waters (Table 3). Three species were consistent indicators of on-shelf copepod communities in all years: Calanus marshallae, Pseudocalanus mimus and Acartia longiremis. Two additional species, Centro-
Table 2. The coefficients of determination $\left(\mathrm{r}^{2}\right)$ for the correlation between ordination distances and original distances and for the maximum correlation of $30 \mathrm{~m}$ temperature, $30 \mathrm{~m}$ denisty, longitude, $1 \mathrm{~m}$ temperature, and chl a with Axis 1

\begin{tabular}{|lcccccc|}
\hline $\begin{array}{l}\text { Year } \\
\text { (n) }\end{array}$ & $\begin{array}{c}\text { Ordination } \\
\text { vs } \\
\text { voriginal }\end{array}$ & $\begin{array}{c}30 \mathrm{~m} \\
\text { temp- } \\
\text { erature }\end{array}$ & $\begin{array}{c}30 \mathrm{~m} \\
\text { ensity }\end{array}$ & $\begin{array}{c}\text { Longi- } \\
\text { tude }\end{array}$ & $\begin{array}{c}\text { 1 } \\
\text { temp- } \\
\text { erature }\end{array}$ & $\begin{array}{c}\text { Chl } a \\
\text { (n) }\end{array}$ \\
\hline $1994(59)$ & 0.86 & 0.87 & 0.73 & 0.62 & 0.53 & $0.36(54)$ \\
$1996(56)$ & 0.91 & 0.77 & 0.46 & 0.81 & 0.52 & $0.02(24)$ \\
$1997(71)$ & 0.90 & 0.77 & 0.67 & 0.68 & 0.26 & $0.45(37)$ \\
$\begin{array}{l}\text { All years } \\
\text { combined (186) }\end{array}$ & 0.84 & 0.76 & 0.56 & 0.63 & 0.39 & $0.18(115)$ \\
\hline
\end{tabular}

Fig. 4. Results of nonmetric multidimensional scaling (NMDS) of 1994, 1996 and 1997 stations in species space. Stations are coded by depth range $(\mathrm{m})$, and all environmental variables with a significant correlation $\left(\mathrm{r}^{2}>0.35\right)$ with Axis 1 are shown. The direction of the arrow indicates the direction of the correlation with the stations and the fraction (\%) of variance in the copepod data explained by that parameter (see Table 2). All ordinations are rotated towards $30 \mathrm{~m}$ temperature, the environmental variable that most often explained the largest fraction of the variance. The dashed line indicates the position along the horizontal axis beyond which no more on-shelf stations occur. Off-shelf stations that fell to the left of this line are labeled. Station labels indicate transect and nautical miles offshore

pages abdominalis and A. hudsonica, were indicators of on-shelf waters in 1994 and 1997. In 1997, Paracalanus parvus was also a good indicator of on-shelf waters.

For off-shelf waters, the species which were good indicators differed among years. As many as 12 species were identified as good indicators of off-shelf conditions in one year or another, but only 4 species appeared as consistent indicators each year; Mesocalanus tenuicornis, Calocalanus styliremis, Clausocalanus spp. and Ctenocalanus vanus (Table 3). Two additional species were off-shelf indicators in 1994 and 
1996; Paracalanus parvus and Oncaea spp., 2 others were off-shelf indicators in 1996 and 1997; Eucalanus californicus and Microsetella spp, and 4 other species were off-shelf indicators in only one of the cruises (see Table 3). In every case, the off-shelf indicator species in question are known to be either subtropical neritic or Transition Zone species (Fleminger 1976). Two of these species, $M$. tenuicornis and $C$. vanus, are 2 of the most frequently occurring species in the central and southern California Current (Fleminger 1967).

\section{Distributions of dominant species}

Spatial variations in the distribution of the 3 dominant subarctic coastal species (Calanus marshallae, Pseudocalanus mimus, and Acartia longiremis) and 3 offshore subtropical and/or Transition Zone species (Mesocalanus tenuicornis, Paracalanus parvus, and Ctenocalanus vanus) are shown in Figs. 5 to 7 . We chose to illustrate these species because they are abundant in all samples (Table 1), and ISA (Table 3) revealed them to be excellent indicators of coastal waters and oceanic waters, respectively. P. mimus had high densities at most on-shelf stations (Fig. 5). Highest densities of C. marshallae (Fig. 5) and A. longiremis (Fig. 6) were seen at the on-shelf stations centered off Newport in 1994. In 1996 and 1997, A. longiremis was most abundant on the Columbia River and Cape Falcon transects, whereas C. marshallae was evenly distributed along the coast. The off-shelf species were usually most abundant along the northern or central transect lines (Figs. 6 \& 7). However, during 1997, $P$. parvus (Fig. 6) had its highest densities in on-shelf waters off the Columbia River and Cape Falcon. $M$. tenuicornis (Fig. 7) was most abundant offshore and to the north in all years. C. vanus (Fig. 7) was most abun- dant offshore and to the north in 1997, but was more evenly distributed in the other $2 \mathrm{yr}$.

The NMDS ordination shown in Fig. 4 was overlaid with the densities of 3 closely related Calanidae species to explore the on-/off-shelf differences (Fig. 8). This analysis showed that Calanus marshallae clustered as a coastal species, Mesocalanus tenuicornis as an off-shelf species, and C. pacificus was distributed throughout both regions (Fig. 8). We compared the 4 Acartia species in the same manner (not illustrated), and found that $A$. hudsonica was present chiefly at the shallowest stations on the shelf, $A$. longiremis in midand outer-shelf samples, and $A$. danae only at the deepest water stations. A. tonsa occurred in only 19 samples and was equally common at both on- and off-shelf stations.

\section{DISCUSSION}

One purpose of this work was to test the hypothesis of on-/off-shelf differences in the biomass, species composition and community structure of copepods in the upwelling zone off Oregon. We found that copepod biomass was similar among years and averaged $16.5 \mathrm{mg} \mathrm{C} \mathrm{m}^{-3}$ (on-shelf, range 14.0 to $19.6 \mathrm{mg} \mathrm{C} \mathrm{m}^{-3}$ ) and $5.9 \mathrm{mg} \mathrm{C} \mathrm{m}^{-3}$ (off-shelf, range 4.2 to $7.7 \mathrm{mg} \mathrm{C} \mathrm{m}^{-3}$ ), with on-shelf biomass greater than off-shelf biomass by a factor of 2.8. The chief reason for this difference in biomass may be related to differences in primary production rates and chlorophyll concentration. The average chl a concentrations during our cruises were $4.4 \mu \mathrm{g}$ $\mathrm{l}^{-1}$ on-shelf and $0.6 \mu \mathrm{g} \mathrm{l}^{-1}$ off-shelf, different by a factor of 7. Perry et al. (1989) also reported higher primary production rates on-shelf compared to off-shelf, averaging 0.95 and $0.33 \mathrm{mg} \mathrm{C} \mathrm{m}^{-2} \mathrm{~d}^{-1}$ respectively for stations off the Washington coast, different by a factor

Table 3. Copepod indicator species ( $\mathrm{p}$ < 0.05) for summer 1994, 1996, and 1997 off the Oregon coast. Species are listed by decreasing order of indicator value within each region

\begin{tabular}{|c|c|c|c|}
\hline Region & 1994 indicator species & 1996 indicator species & 1997 indicator species \\
\hline On-shelf & $\begin{array}{l}\text { Acartia longiremis } \\
\text { Centropages abdominalis } \\
\text { Pseudocalanus mimus } \\
\text { Calanus marshallae } \\
\text { Acartia hudsonica }\end{array}$ & $\begin{array}{l}\text { Calanus marshallae } \\
\text { Acartia longiremis } \\
\text { Pseudocalanus mimus }\end{array}$ & $\begin{array}{l}\text { Calanus marshallae } \\
\text { Acartia longiremis } \\
\text { Centropages abdominalis } \\
\text { Pseudocalanus mimus } \\
\text { Paracalanus parvus } \\
\text { Acartia hudsonica }\end{array}$ \\
\hline Off-shelf & $\begin{array}{l}\text { Clausocalanus spp. } \\
\text { Ctenocalanus vanus } \\
\text { Paracalanus parvus } \\
\text { Mesocalanus tenuicornis } \\
\text { Calocalanus styliremis } \\
\text { Oncea sp. } \\
\text { Metridia pacifica } \\
\text { Corycaeus anglicus }\end{array}$ & $\begin{array}{l}\text { Oncaea spp. } \\
\text { Clausocalanus spp. } \\
\text { Ctenocalanus vanus } \\
\text { Calocalanus styliremis } \\
\text { Microsetella sp. } \\
\text { Mesocalanus tenuicornis } \\
\text { Paracalanus parvus } \\
\text { Eucalanus bungii californicus }\end{array}$ & $\begin{array}{l}\text { Calocalanus styliremis } \\
\text { Ctenocalanus vanus } \\
\text { Microsetella sp. } \\
\text { Clausocalanus spp. } \\
\text { Eucalanus bungii californicus } \\
\text { Mesocalanus tenuicornis } \\
\text { Acartia danae } \\
\text { Candacia bipinnata }\end{array}$ \\
\hline
\end{tabular}



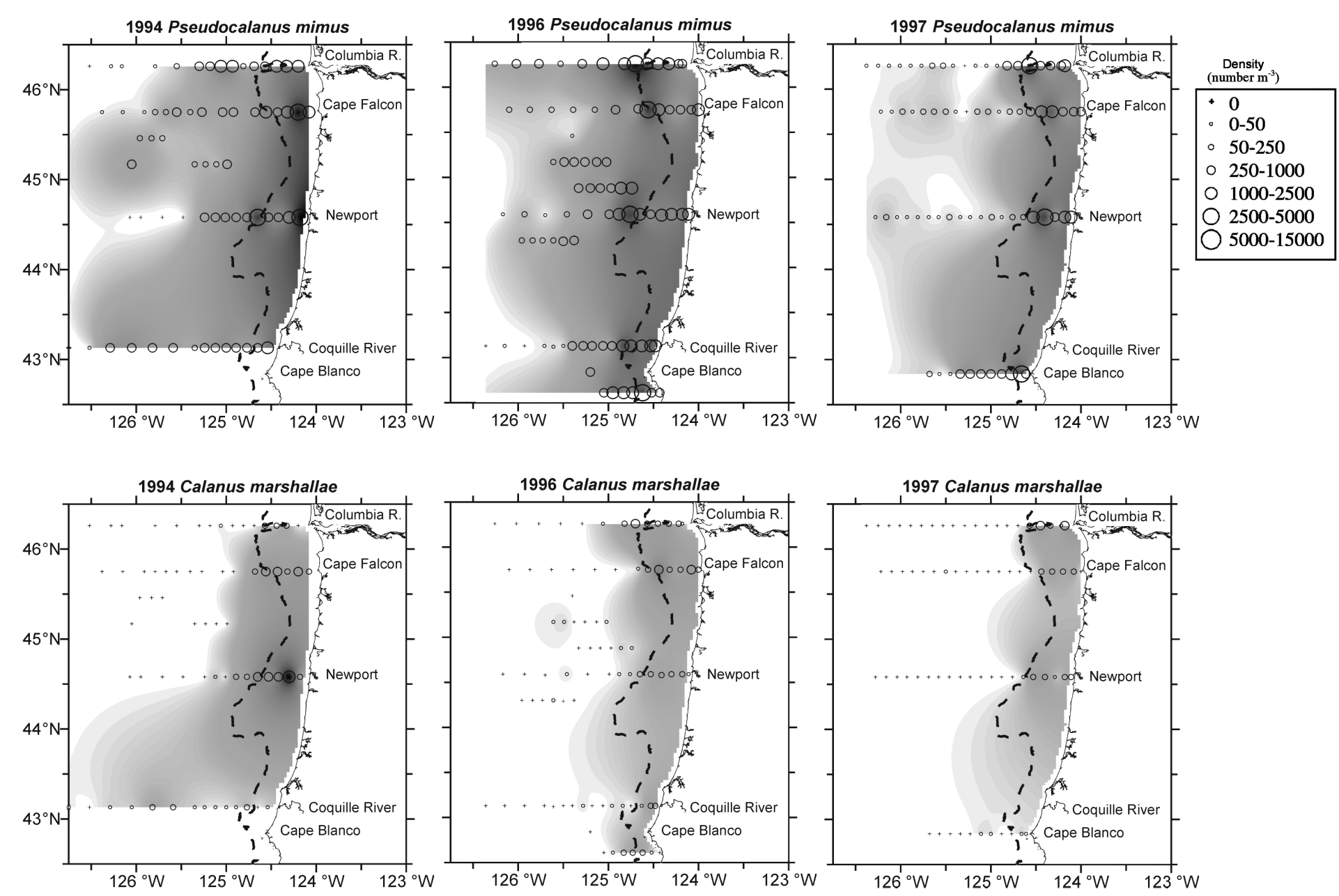

Fig. 5. Density estimates of Pseudocalanus mimus and Calanus marshallae off the Oregon coast, USA from stations (+) along 4 hydrographic transects: Columbia River (CR), Cape Falcon (CF), Newport (NH), and Coquille River (CQ) during 6 to 26 July 1994 and 9 to 21 June 1996; CR, CF, NH, and Cape Blanco (CB) during 14 to 25 July 1997. The dashed line indicates the $180 \mathrm{~m}$ depth contour

of 3. Thus, higher copepod biomass and copepod production in on-shelf waters would be expected. This was confirmed during the June 1996 cruise, during which Peterson et al. (2002) measured copepod growth rates at 37 on-shelf stations and 36 off-shelf stations and calculated copepod production. They found that copepod production averaged $2.3 \mathrm{mg} \mathrm{C} \mathrm{m}^{-3} \mathrm{~d}^{-1}$ for the on-shelf stations and $0.8 \mathrm{mg} \mathrm{C} \mathrm{m}^{-3} \mathrm{~d}^{-1}$ for the off-shelf waters, differing by a factor of 2.9. Thus, differences between on- and off-shelf plankton biomass and production were similar; phytoplankton biomass (as chlorophyll), primary production, copepod biomass and secondary production were all greater in on-shelf waters than off-shelf waters by a factor of $\geq 3$.

Not only were there on-/off-shelf variations in copepod biomass, but we also observed differences in copepod community structure. We suggest that these differences in both copepod biomass and species composition derive from the different origins of the source waters for on- and off-shelf habitats. For example, 3 copepod species were consistently more abundant only at the on-shelf stations: Calanus marshallae, Pseudocalanus mimus, and Acartia longiremis. We know that these species dominate shelf waters off Newport, Oregon (Peterson \& Miller 1975) as well as coastal waters to the north; Vancouver Island (Mackas et al. 2001), Gulf of Alaska (Coyle et al. 1990), and the Bering Sea (Johnson \& Brinton 1963). Thus, these 3 species are good indicators of the presence of Gulf of Alaska coastal water on the Oregon shelf.

On the other hand, offshore California Current waters are dominated by a mixture of copepod species, some from the Transition Zone (Tables 1 and 3), and others that are typical of the temperate-subtropical coastal neritic regions of central and southern California. The Transition Zone is a band of water that extends between about 40 and $45^{\circ} \mathrm{N}$ across the Pacific Ocean from Japan to Oregon and northern California. 

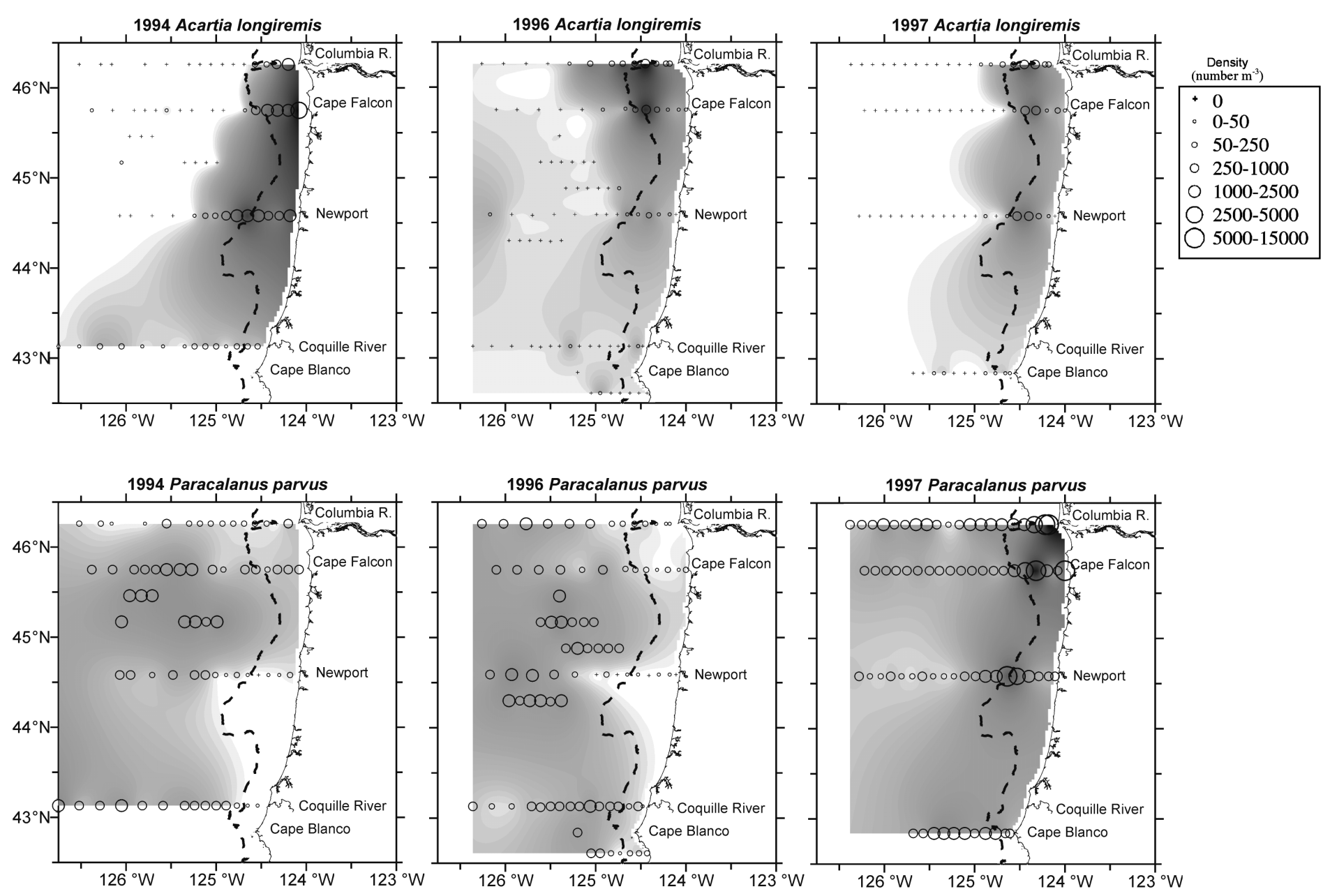

Fig. 6. Density estimates of Acartia longiremis and Paracalanus parvus off the Oregon coast, USA from stations (+) along 4 hydrographic transects: Columbia River (CR), Cape Falcon (CF), Newport (NH), and Coquille River (CQ) during 6 to 26 July 1994 and 9 to 21 June 1996; CR, CF, NH, and Cape Blanco (CB) during 14 to 25 July 1997. The dashed line indicates the $180 \mathrm{~m}$ depth contour

Copepod species that are typical of the Transition Zone include Mesocalanus tenuicornis, Calanus pacificus, Eucalanus californicus and Candacia bipinnata (Fleminger 1967). Subtropical neritic species are also commonly found in offshore waters during summer and include Paracalanus parvus, Ctenocalanus vanus, Acartia tonsa and Corycaeus anglicus (Fleminger 1967, Barnett \& Jahn 1987). These species are more typically found in coastal waters of central and southern California, but they prosper in deep waters off Oregon. We commonly found Clausocalanus species with the warm-water group. The systematics of this genus are difficult, and we did not attempt to routinely identify them to species. However, detailed analysis of additional samples collected at biweekly intervals at several on-shelf stations off Newport, Oregon from 1996 to present, reveal that the dominant species are C. arcuicornis, C. pergens and C. paragergens (Peter- son et al. 2002). These species are also known to be Transition Zone species (Frost \& Fleminger 1968). Thus, though the offshore copepod community has mixed affinities, all species can be classified as 'warm water' species. These observations collectively support the physical oceanographic paradigm of Hickey (1998) that waters offshore of the continental shelf in the northern California Current region have their origins in the Transition Zone and the west wind drift.

It is noteworthy that the 'offshore community' consisting of subtropical and Transition Zone copepod species is virtually the same copepod community that occurs in coastal waters off Oregon and Washington during winter months (Peterson \& Miller 1977, their Table 1). During winter months, southwesterly storms transport offshore waters (and offshore copepods) onshore, resulting in downwelling at the coast. In addition, the northward-flowing coastal Davidson Current 

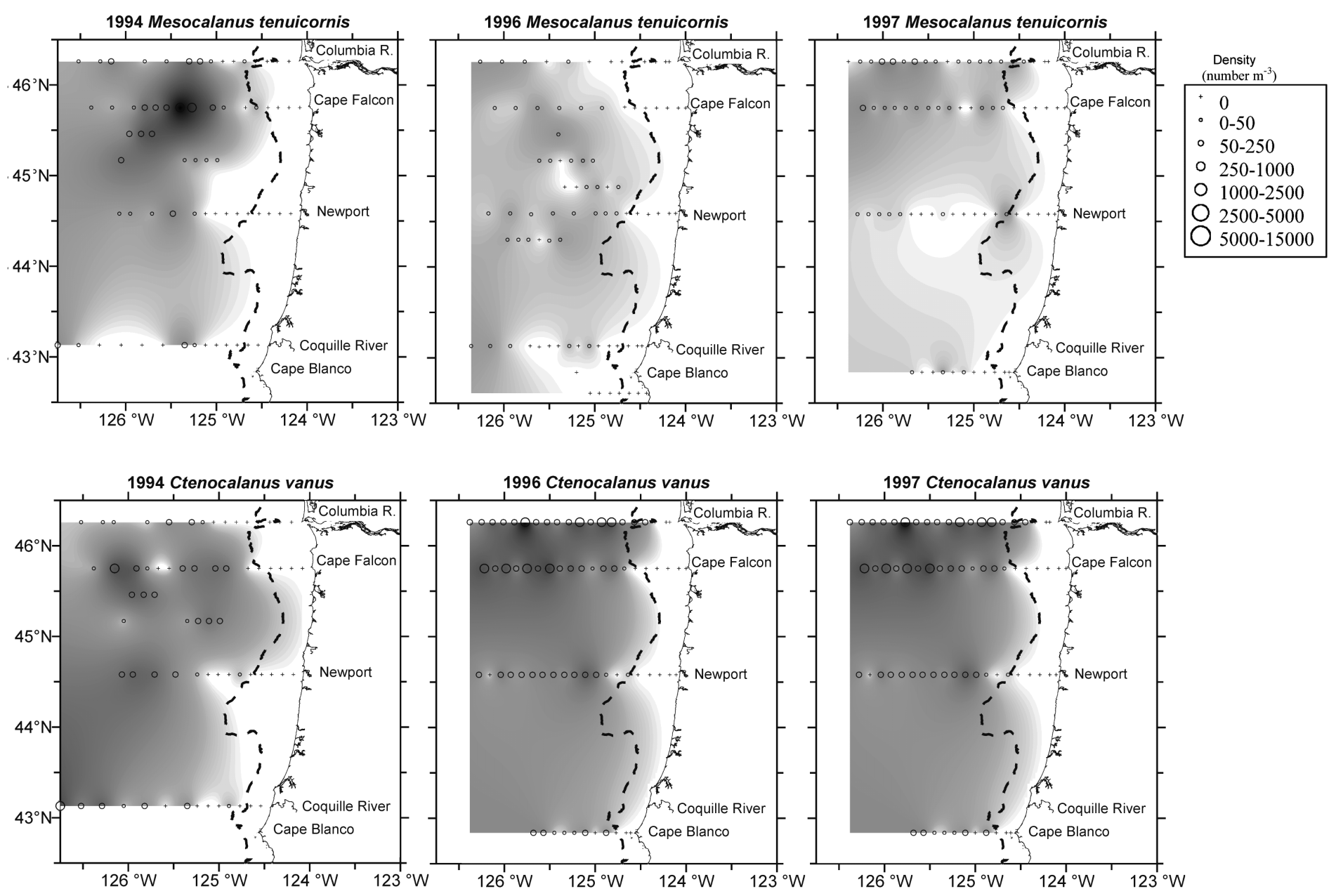

Fig. 7. Density estimates of Mesocalanus tenuicornis and Ctenocalanus vanus off the Oregon coast, USA from stations (+) along 4 hydrographic transects: Columbia River (CR), Cape Falcon (CF), Newport (NH), and Coquille River (CQ) during 6 to 26 July 1994 and 9 to 21 June 1996; CR, CF, NH, and Cape Blan (CB) during 14 to 25 July 1997. The dashed line indicates the $180 \mathrm{~m}$ depth contour

advects warm-water subtropical neritic copepods (such as Paracalanus parvus, Ctenocalanus vanus and Corycaeus anglicus) from the California shelf to Oregon shelf waters. We speculate that these warm water neritic copepod species are found offshore of Oregon during summer because they are advected offshore in spring when upwelling commences, and subsequently remain in the offshore area during spring and summer months because southward flows in the offshore California Current are sluggish (Hickey 1998). This explains why the offshore copepod community off Oregon is a mixture of species of different origins, some are transported from the west wind drift, whereas others are permanent residents of the northern California Current that live offshore in summer but in continental shelf waters in winter.

We found that the geographic location between the on- and off-shelf community occurred at or just off- shore of the shelf break. The fidelity of the separation of on- and off-shelf communities was very high, with more than $94 \%$ of our stations grouped along an onshore-offshore environmental gradient. The few stations that did not group exactly with other members of their community are indicated on Fig. 3 by their station (transect letter and distance in nautical miles offshore). Misclassification occurred where upwelling was particularly strong in association with a headland: Cape Falcon in 1996 and 1997, and Cape Blanco (Stations CQ 15 in 1994, and CB 10 and 20 in 1997. Capes are regions of high offshore transport, particularly Cape Blanco (Barth et al. 2000). It is common for coastal copepods to be transported offshore in that region (Peterson \& Keister 2002). Another example of offshore transport was in 1996 along the Columbia River transect, where offshore transport of coastal species by the Columbia River plume probably occurred. 


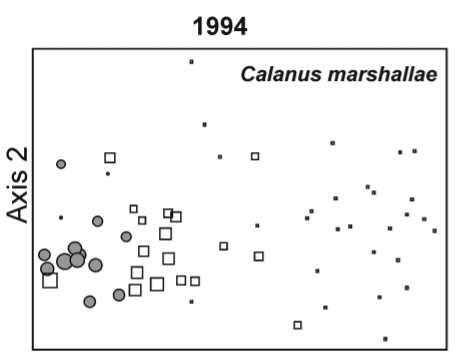

Axis 1

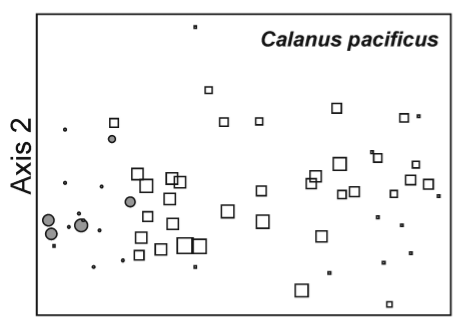

Axis 1

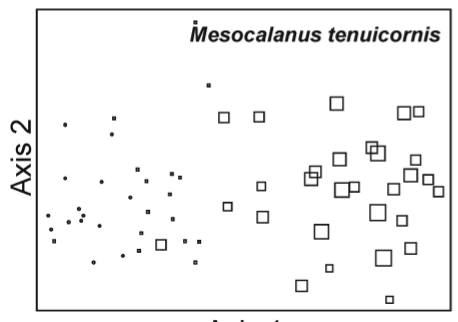

Axis 1

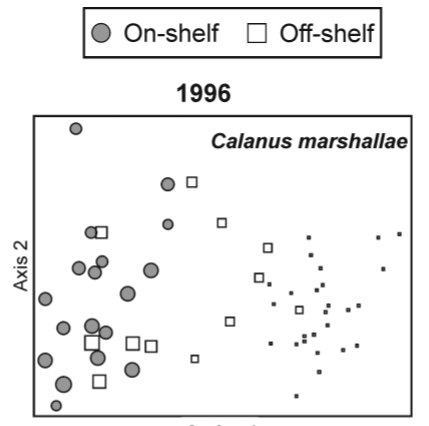

Axis 1

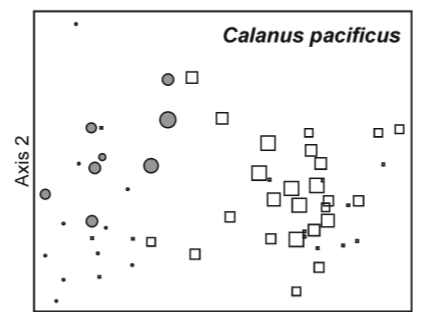

Axis 1

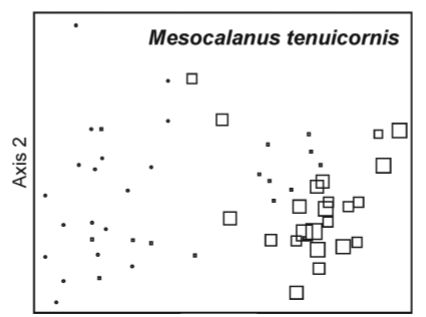

Axis 1
1997

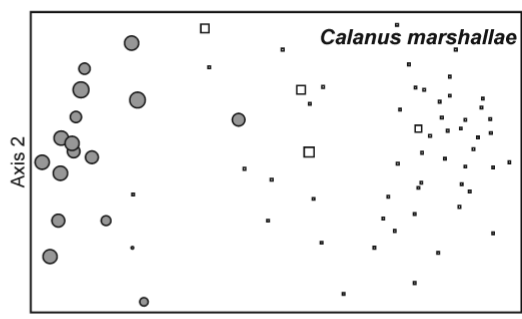

Axis 1

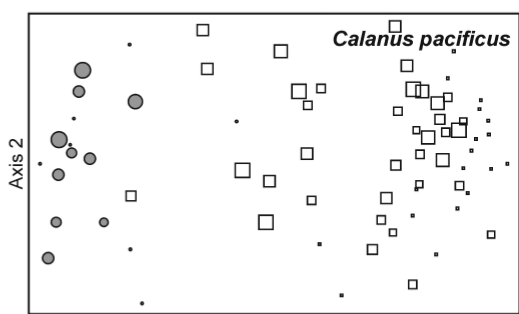

Axis 1

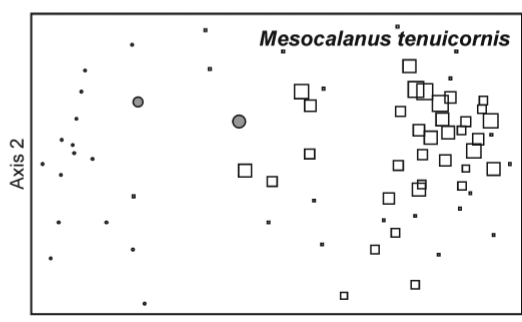

Axis 1

Fig. 8. Results of non-metric multidimensional scaling (NMDS) of 1994, 1996 and 1997 stations in species space. Stations are coded by whether they occur on-shelf ( $\leq 180 \mathrm{~m}$ depth) or off-shelf ( $>180 \mathrm{~m}$ depth). The size of the symbol is relative to the density of Calanus marshalle, C. pacificus, or Mesocalanus tenuicornis at that station, with the smallest symbol representing none of that species present. All ordinations were rotated towards longitude. Axis scales in NMDS are relative, based on non-metric ranking of similarity and therefore not shown

Hickey (1998) emphasized that variability in currents over the continental shelf off Washington and Oregon have different time and space scales from currents seaward of the shelf. Moreover, the degree to which the off-shelf California Current interacts with coastal waters is unclear (Hickey 1989, p. 43-45). There are evidently no sharp boundaries in hydrographic properties between waters, and rather a gradual transition from cold salty water on the shelf to warm fresher water off the shelf. Recent drifter observations suggest that, at least in the upper layers of the water column, the interactions between the shelf and slope waters are quite weak (J. Barth unpubl. data, available at http://diana.coas.oregonstate.edu/drift/recent.shtml). Drifters launched in on-shelf waters off Newport during summer invariably move south at high speeds and remain in on-shelf waters until at least the latitude of Cape Blanco $\left(42.5^{\circ} \mathrm{N}\right)$. However, drifters launched in slope waters (40 to $50 \mathrm{~km}$ from shore) often move to the west or meander about the area. Thus, we suggest that the apparent lack of interaction between the 2 water types may partially explain why we observed 2 distinct copepod communities.

Another related mechanism that could explain separation of the 2 copepod communities is related to offshore transport during coastal upwelling. Active coastal upwelling does not extend beyond the shelf break off central Oregon (Huyer 1983) thus coastal species will not normally be transported beyond the shelf. Earlier papers (Peterson et al. 1979, Peterson 1998) found that coastal copepod species are retained in coastal upwelling zones through ontogenetic migration. We suggest that the retention mechanisms that keep coastal species on the shelf may explain the strong contrasts in copepod community structure between on-shelf and off-shelf waters. That is, in the region of central Oregon, coastal copepod species are not transported offshore beyond the shelf break during upwelling, and upwelling prevents offshore species from being transported onshore. 
Another possible mechanism accounting for the shelf-oceanic gradient in copepod community structure is related to the relative ability of species to survive in a different water types. That is, should there be an exchange of shelf and slope waters through some physical process, oceanic species may not survive in coastal waters and vice versa. Oceanic species are adapted to relatively particle-free oligotrophic water, and may be incapable of feeding in particle-rich waters with chloro-

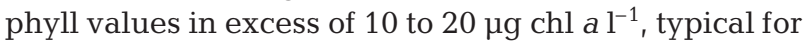
summertime off the Oregon and Washington coasts. The shelf environment is dominated by diatoms while the offshore oligotrophic environment is dominated by nannophytoplankton (Evelyn Sherr pers. comm.). Differences in availability of food type and size may explain why coastal species prosper in coastal regions and subtropical species prosper in oligotrophic waters, but not vice versa. There are strong temperature gradients between shelf and slope waters. The cool waters on the shelf might prevent successful colonization of shelf waters by offshore, warm-adapted, species. Similarly, cold-adapted shelf species may also be unable to survive in relatively warm and particle-free oligotrophic waters offshore of the shelf. Finally, predator guilds are different between coastal and oceanic waters, with coastal waters dominated by ctenophores, scyphomedusae, and zooplanktivorous fishes (osmeriids and clupeids) and oceanic waters by Pacific saury Cololabis saira, mesopelagic fishes (at night), and euphausiids. Thus, a variety of biological interactions coupled with weak offshore Ekman transport and weak interaction of shelf and slope waters may also explain the observed zonation in copepod communities.

Our observation of a separation between an on- and off-shelf copepod community in association with the continental shelf break appears to be a general result, being common to both upwelling and non-upwelling regions. For example, separation of water types and copepod community types occurs at or near the shelf break in most coastal upwelling regions: Baja California (Longhurst 1967, Cervantes-Duarte et al. 1993), Peru (Santander 1981), southwest Brazil off Cabo Frio (Lopes et al. 1999), and Cap Blanc, Mauritania (Kuipers et al. 1993). To cite only a few examples from non-upwelling regions, Fernández-Alamo et al. (2000) found the limit between a neritic and oceanic copepod assemblage corresponded largely with the border of the continental shelf in the Gulf of Tehuantepec, as did Seridji \& Hafferssas (2000) for the Mediterranean Sea off the coast of Algeria, Siokou-Frangou et al. (1998) in the Aegean Sea, and Grice \& Hart (1962) for the continental shelf off New York. On the other hand, shelf-slope zonation in copepod community structure is not observed in upwelling systems with strong wind forcing and a very narrow shelf such as off northern Chile $\left(23^{\circ} \mathrm{N}\right)$ (Escrib- ano \& Hildalgo 2000), and Somalia (NE Africa) (Smith 1982). In these systems, coastal animals are displaced great distances from shore into off-shelf waters.

In conclusion, the copepod communities off the Oregon coast closely resemble the structure of the dominant water masses. Species in coastal waters reflect their Gulf of Alaska origins, whereas species in offshore waters are warm water species of mixed origins. Clearly, some species are advected into the offshore region from the west wind drift and Transition Zone. Others, are warm water neritic species with origins in shelf waters of central and southern California. These warm water neritic species are advected to Oregon's coastal waters in winter by the Davidson Current. We speculate that during spring and summer, these warm-water species are advected to offshore waters by coastal upwelling, where they establish viable populations because equatorward advection is slow. We suggest that the coastal copepod community remains separated from the offshore community through a combination of factors, including weak physical interaction between shelf and offshore waters, and lack of direct exchange of coastal waters with oceanic waters.

Acknowledgements. We thank the captain and crew of the RVs 'Sea Otter' and 'McArthur' for their cooperation and assistance during these cruises. We would especially like to thank P. J. Bentley for his participation and hard work during all of the cruises. This project was partially funded by a NOAA/Recovery Protected Species grant to R.L.E. We thank J. Keister, Dr. C. B. Miller, and 3 referees for comments on the manuscript.

\section{LITERATURE CITED}

Barnett AM, Jahn AE (1987) Pattern and persistence of a nearshore planktonic ecosystem off Southern California. Cont Shelf Res 7(1):1-25

Barth JA, Pierce SD, Smith RL (2000) A separating coastal upwelling jet at Cape Blanco, Oregon and its connection to the California current system. Deep-Sea Res II 47(5-6): 783-810

Bentley PJ, Emmett RL, Lo NCH, Moser G (1996) Egg production of Pacific sardine (Sardinops sagax) off Oregon in 1994. CalCOFI Rep 37:193-200

Bray JR, Curtis JT (1957) An ordination of the upland forest communities in southern Wisconsin. Ecol Monogr 27(4): $325-349$

Cervantes-Duarte R, Aguniga Garcia S, Hernandez Trujillo S (1993) Upwelling conditions associated to the distribution of zooplankton in San Hipolito, BCS. Ciencias Mar 19(1): 117-135

Chiba S, Ishimaru T, Hosie GW, Fukuchi M (2001) Spatiotemporal variability of zooplankton community structure off east Antarctica (90 to $160^{\circ}$ E). Mar Ecol Prog Ser 216: 95-108

Coyle KO, Paul AJ, Ziemann DA (1990) Copepod populations during the spring bloom in an Alaskan subarctic embayment. J Plankton Res 12(4):759-797

Cross FA (1964) Seasonal and geographical distribution of 
pelagic copepods in Oregon coastal waters. MS thesis, Oregon State University, Corvallis

Cross FA, Small LF (1967) Copepod indicators of surface water movements off the Oregon coast. Limnol Oceanogr 12:60-72

Dufrene M, Legendre P (1997) Species assemblages and indicator species: the need for a flexible asymmetrical approach. Ecol Monogr 67(3):345-366

Escribano R, Hidalgo P (2000) Spatial distribution of copepods in the north of the Humbolt Current region off Chile during coastal upwelling. J Mar Biol Assoc UK 80(2):283-290

Fernández-Alamo MA, Sanvicente-Anorve L, Alameda-DeLa-Mora G (2000) Copepod assemblages in the Gulf of Tehuantepec, Mexico. Crustaceana 73(9):1139-1153

Field JG, Clarke KR, Warwick RM (1982) A practical strategy for analyzing multispecies distribution patterns. Mar Ecol Prog Ser 8:37-52

Fleminger A (1967) Distributional atlas of calanoid copepods in the California Current region, Part II. California Cooperative Oceanic Fisheries Investigation Atlas No. 7, xvi + 1-213 plates

Frost BW, Fleminger A (1968) A revision of the genus Clausocalanus (Copepoda: Calanoida) with remarks on distributional patterns in diagnostic characters. Bull Scripps Inst Oceanogr 12:1-235

Grice GD, Hart AD (1962) The abundance, seasonal occurrence and distribution of the epizooplankton between New York and Bermuda. Ecol Monogr 32:287-309

Hickey BM (1989) Pattern and process of circulation over the Washington continental shelf and slope. In: Landry MR, Hickey BM (eds) Coastal oceanography of Washington and Oregon. Elsevier Oceanogr Ser 47:41-115

Hickey BM (1998) Coastal Oceanography of western North America from the tip of Baja California to Vancouver Island (coastal segment 8E). In: Robinson AR, Brink KH (eds) The sea: ideas and observations on progress in the study of the seas. The global coastal ocean: regional studies and syntheses. Interscience Publishers, New York, p 345-393

Hosie GW, Cochran RG (1994) Mesoscale distribution patterns of macrozooplankton communities in Prydz Bay, Antarctica-January to February 1991. Mar Ecol Prog Ser 106:21-39

Huyer A (1983) Coastal upwelling in the California Current system. Prog Oceanogr 12:259-284

Johnson MW, Brinton E (1963) Biological species, watermasses and currents. In: Hill M (ed) The sea, Vol 2. Interscience Publishers, New York, p 381-414

Kruskal JB (1964) Nonmetric multidimensional scaling: a numerical method. Psychometrika 29:1-27

Kuipers BR, Witte HJ, Gonzalez SR (1993) Zooplankton distribution in the coastal upwelling system along the Banc d'Arguin, Mauritania. Hydrobiologia 258:133-149

Landry MR, Lorenzen CJ (1989) Abundance, distribution, and grazing impacts of zooplankton on the Washington shelf. In: Landry MR, Hickey BM (eds) Coastal Oceanography of Washington and Oregon. Elsevier Oceanogr Ser 47:175-210

Longhurst A (1967) Diversity and trophic structure of zooplankton communities in the California Current. DeepSea Res 14:393-408

Lopes RM, Brandini FP, Gaeta S (1999) Distribution patterns of epipelagic copepods off Rio de Janeiro (SE Brazil) in summer 1991/1992 and winter 1992. Hydrobiologia 411: 161-174

Mackas DL, Thomson RC, Galbraith M (2001) Changes in the zooplankton community of the British Columbia continental margin, 1985-1999, and their covariation with oceanographic conditions. Can J Fish Aquat Sci 58:685-702
Mather PM (1976) Computational methods of multivariate analysis in physical geography. J Wiley \& Sons, London

McCune B, Mefford MJ (1999) Multivariate analysis of ecological data, Version 4.36 beta. MjM Software, Gleneden Beach, OR

Mielke PW Jr (1984) Meterological applications of permutation techniques based on distance functions. In: Krishnaiah PR, Sen PK (eds) Handbook of statistics, Vol 4. Nonparametric methods. Elsevier Science Publishers, Amsterdam, p 813-830

Perry MJ, Bolger JP, English DC (1989) Primary production in Washington coastal waters. Elsevier Oceanogr Ser 47: $117-138$

Peterson W (1998) Life cycle strategies of copepods in coastal upwelling zones. J Mar Syst 15(1-4):313-326

Peterson WK (1972) Distribution of pelagic Copepoda off the coasts of Washington and Oregon during 1961 and 1962. In: Pruter AT, Alverson DL (eds) The Columbia River Estuary and adjacent ocean waters. University of Washington Press, Seattle, p 313-343

Peterson WT, Keister JE (2002) The effect of a large cape on distribution patterns of coastal and oceanic copepods off Oregon and northern California during the 1998-1999 El Niño-La Niña. Prog Oceanogr 53(2-4):389-411

Peterson WT, Miller CB (1975) Year-to-year variations in the planktology of the Oregon upwelling zone. Fish Bull 73(3): 642-653

Peterson WT, Miller CB (1977) Seasonal cycle of zooplankton abundance and species composition along the central Oregon coast. Fish Bull 75(4):717-724

Peterson WT, Miller CB, Hutchinson A (1979) Zonation and maintenance of copepod populations in the Oregon upwelling zone. Deep-Sea Res 26A:467-494

Peterson WT, Gómez-Gutiérrez J, Morgan CA (2002) Crossshelf variation in calanoid copepod production during summer 1996 off the Oregon coast, USA. Mar Biol 141:353-365

Peterson WT, Keister JE, Feinberg L (2002) The effects of the 1997-1999 El Niño/La Niña events on hydrography and zooplankton off the central Oregon coast. Prog Oceanogr 54(1-4):381-398

Santander BH (1981) The zooplankton in an upwelling area off Peru. In: Richards FA (ed) Coastal upwelling, coastal and estuarine sciences (1). American Geophysical Union, Washington, DC, p 411-416

Seridji R, Hafferssas A (2000) Copepod diversity and community structure in the Algerian Basin. Crustaceana 73(1):1-23

Shaw W, Robinson CLK (1998) Night versus day abundance estimates of zooplankton at two coastal stations in British Columbia, Canada. Mar Ecol Prog Ser 175:143-153

Siokou-Frangou I, Papahanassiou E, Lepretre A, Frontier S (1998) Zooplankton assemblages and influence of environmental parameters on them in a Mediterranean coastal area. J Plankton Res 20(5):847-870

Smith PE, Flerx W, Hewitt RP (1985) The CalCOFI vertical egg two (CalVET) net. In: Lasker (ed) An egg production method for estimation spawning biomass of pelagic fish: application to the northern anchovy (Engraulis mordax). US Dept Comm, NOAA Tech Rep NMFS 36:27-32

Smith SL (1982) The northwestern Indian Ocean during the monsoons of 1979: distribution, abundance, and feeding of zooplankton. Deep-Sea Res 29(11A):1331-1353

Strub PT, James C (2002) The 1997-1998 oceanic El Niño signal along the southeast and northeast Pacific boundariesan altimetric view. Prog Oceanogr 54(1-4):439-458

Zimmerman GM (1985) Use of an improved statistical method for group comparisons to study effects of prairie fire. Ecology 66(2):606-611

Submitted: August 30, 2001; Accepted: October 30, 2002

Proofs received from author(s): February 24, 2003 